\title{
Sivas bölgesinde buğday üretiminde yakıt enerji verimliliğine etki eden faktörlerin araştırılması
}

\author{
Investigation of factors affecting the fuel energy productivity in wheat production of \\ Sivas region
}

\author{
Ferhat KÜP ${ }^{1 *}$ D , Abdullah TURGUD ${ }^{1}$ \\ ${ }^{1}$ Harran Üniversitesi, Ziraat Fakültesi, Tarım Makinaları ve Teknolojileri Mühendisliği, 63200, Şanlıurfa
}

\section{To cite this article:}

Küp, F. \& Turgud, A. (2020).

Sivas bölgesinde buğday

üretiminde yakıt enerji

verimliliğine etki eden faktörlerin araştırılması.

Harran Tarım ve Gıda Bilimleri Dergisi, 24(1): 73-84. DOI:10.29050/harranziraat.628795

\author{
Address for Correspondence: \\ Ferhat KÜP \\ e-mail: \\ ferkup63@harran.edu.tr
}

Received Date:

03.10.2019

Accepted Date:

24.02.2020

(C) Copyright 2018 by Harran University Faculty of Agriculture. Available on-line at www.dergipark.gov.tr/harranziraat

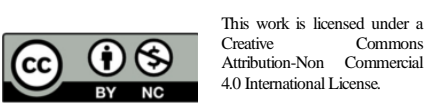

\section{Öz}

Tarımsal üretimde en büyük girdi enerjidir. Bundan dolayı enerji verimliliği tarımsal üretimde azami derecede dikkate alınması gereken bir konudur. Üretimde önemli bir girdi olan enerjinin verimli olarak minimum düzeyde kullanılması, çiftçilere daha az bir girdi sağlayıp üretimde elde edilen kârı artırmaktadır. Bu çalışma Sivas ilinde buğday üretiminde tüketilen yakıt enerjisine etki edebilecek etmenlerin belirlenmesi için 2017-2018 yılları arasında arazi koşullarında yapılmıştır. Tüketilen yakıt enerjisine etki eden etmenler olarak arazi eğimi, arazi toprak yapısı ve arazi taşlık değeri dikkate alınmıştır. Bu çalışmadaki amaç, tüketilen yakıt enerjisi ile buna etki eden etmenlerin karşılaştırılmasının yapılmasıdır. Araştırmanın sonucunda incelenen etmenlerin (arazi eğimi, toprak yapısı, taşlılık) \%70 oranında yakıt enerjisini etkilediği görülmüştür. Bu etmenlerden arazinin eğimi, tüketilen enerji değişkenini \%47 oranında etkilemiştir. Sonuç olarak arazi eğiminin azaltılması, toprak yapısının dengelenmesi, taşlılık değerinin azaltılması vb. yapılacak düzenlemelerle enerji verimliliğinin arttırılabileceği görülmüştür.

Anahtar Kelimeler: Buğday üretimi, Enerji verimliliği, Yakıt enerjisi

\section{ABSTRACT}

Energy is the largest input in agricultural production. Therefore energy efficiency is an issue that should be considered in the high degree of importance in agricultural production. The efficient use of energy, which is an important input in production, at a minimum level, provides less input to farmers and increases the profit obtained in production. This study was carried out in 2017-2018 in field conditions in order to investigate the factors that may affect the fuel energy consumed in wheat production in Sivas Region. Land slope, land soil structure and land stony value were taken into consideration as factors affecting fuel energy consumed. The aim of this study is to compare the fuel energy consumption and the factors affecting fuel energy consumption. As a result of the research, it was observed that the factors examined (land slope, soil structure, stonyness) affect the use of fuel energy by $70 \%$. Of these factors, the slope of the land affects the energy consumption variable consumed by $47 \%$. As a result, it is seen that energy efficiency can be increased by reducing land slope, balancing soil structure, reducing stony value and similar arrangements.

Key Words: Wheat production, Energy productivity, Fuel energy

\section{Giriş}

Dünyanın gelecekteki en büyük sorunlarından üçü su, enerji ve gıda güvenliğidir. Gelecekte Dünyanın bu sorunları çözmesi için üretimde verimliliğin arttırılması, alternatif çevreci üretim yöntemlerinin kullanılması vb. ile ilgili çalışmalar yoğun bir şekilde devam etmektedir. Özellikle enerji ve enerji verimliliğinin arttırılmasına yönelik çalışmalar büyük öneme sahiptir. Günümüzde 
üretimin her dalında büyük bir oranda fosil yakıtlar kullanılmaktadır. Fosil yakıtların çevreye verdiği zararlar ve tükenebilir olması sebebiyle bu yakıtlarla ilgili alınacak iki tedbir vardır. Bunlar, alternatif enerji kaynaklarının kullanılması diğeri ise enerji verimliliğinin arttırılmasıdır. Günümüzde alternatif enerji kaynakları olarak güneş enerjisi, rüzgar enerjisi, su enerjisi biokütle enerjisi, jeotermal enerji vb. kullanılmaktadır. Okant (2012), tarafından yapılan çalışmada Biodizel yakıtının zararlı emisyon yayma miktarının düşük olmasından dolayı toplu taşıma araçlarında, deniz ulaşımında, ormanlarda vb. kullanılabileceğini belirtmiştir. Bununla birlikte sektörel bazda yakıt enerji verimliliğinin arttırılması da büyük öneme sahiptir. Enerji verimliliği, binalarda yaşam standardı ve hizmet kalitesinin, endüstriyel işletmelerde ise üretim kalitesi ve miktarının düşüşüne yol açmadan, birim veya ürün miktarı başına enerji tüketiminin azaltılmasıdır (ETKB, 2019). Enerji verimliliğini sağlamanın üç yolu vardır. Birinci yolu alternatif enerji kaynakları kullanmak, ikincisi ürün miktarını arttırmak, diğeri ise enerjiye etki eden faktörleri belirleyerek bunları enerjiyi azaltacak şekilde düzenlemektir. Enerji verimliliği, sürdürülebilir bir küresel enerji sisteminin ilk unsurudur. Enerji verimliliği, çevresel ve sosyal faydalar sağlarken iklim değişikliğini azaltabilir, enerji güvenliğini artırabilir ve ekonomileri büyütebilir (IEA, 2019). Türkiye'de ilk olarak 5627 sayılı Enerji Verimliliği Kanunu, 2 Mayıs 2007 tarihli 26510 sayılı resmi gazetede yayımlanarak yürürlüğe girmiştir. Bununla birlikte bina, sanayi ve birçok sektörde enerji verimliliğinin düzenlenmesi ile ilgili çalışmalar başlamıştır. Enerji verimliliği en önemli eylem önceliği olarak algılanmaya devam etmektedir. Türkiye, 2023 yılına kadar birincil enerji tüketiminin \%14'ünü azaltacak uygulamaları ortaya koyan Ulusal Enerji Verimliliği Eylem Planını Ocak 2018'de ilan etmiştir. Eylem Planı, 10.9 milyar $A B D$ doları tutarında planlı yatırım içeren bir stratejiyle Türkiye'nin birincil enerji tüketiminden 23.9 milyon ton tasarruf etmeyi amaçlamaktadır. Öngörülen toplam yatırımın geri dönüşünün 2033 yılına kadar 30 milyar ABD doları olması beklenmektedir. Planda belirtilen sektörel önlemler arasında binalar ve hizmetler, enerji, ulaştırma, endüstri ve teknoloji, tarım ve kesişen alanlar bulunmaktadır. Eylem Planının 2019 yılında sonuçlandırılması ve her bir kategori altındaki uygulamanın aynı yıl içerisinde netleştirilmesi beklenmektedir (WEC, 2019). Iqbal (2007) yaptığı çalışmada geleneksel tarımdan modern tarıma geçiş devresinde ticari enerji kullanımının da keskin bir şekilde arttığını belirtmiştir. Tarımda farklı ürünler için enerji ile ilgili çalışmalar yapılmaktadır. Çelen ve ark. (2017) elma yetiştiriciliğinde enerji girdi-çıtıtı analizi yapmışlardır. Sonuçta genel enerji girdileri içerisinde en yüksek enerji tüketiminin sırasıyla gübre enerjisi, yakıt-yağ enerjisi, kimyasallar, makine, insan işgücü ve sulama enerjisi olduğunu belirtmişlerdir. Altuntaş ve ark. (2019) Sivas ili Gürün ilçesinde kuru tarım şartlarında buğday üretimi için farklı toprak işleme yöntemlerinin enerji tüketimine olan etkisini incelemişlerdir. Sonuç olarak Enerji oranı, özgül enerji, enerji verimliliği ve enerji kârlılığı açısından, geleneksel toprak işleme yöntemi yerine doğrudan ekim, koruyucu toprak işleme ve azaltılmış toprak işleme sistemlerinin kullanılabileceğini belirtmişlerdir. Alipour ve ark. (2012) yaptıkları çalışmanın sonucunda, hedeflenen pirinç tarlalarında kullanılan sulama, elektrik ve (N) gübre kullanımının gerekenden fazla olduğunu belirtmişler. Bununla birlikte asıl amacın girdileri düşürmek değil girdilerin verimli bir şekilde kullanılması olduğunu vurgulamışlardır. Afshar ve ark. (2013) 2019-2010 yılları arasında İran'ın Markazi bölgesindeki fıstık üretimi için yaptıkları ekonomik analizde mevcut uygulamalar ile enerji verimliliğinin sağlanmadığını ve enerji kullanım verimliliğini artırmak için çaba gösterilmesi gerektiğini ortaya koymuşlardır. Golaszewski ve ark, (2014) Avrupa'nın farklı iklim koşullarında buğday üretiminde meydana gelen enerji verimliliğini incelemişlerdir. Sonuçta enerji tasarrufu ile ilgili faaliyetlerin belli bölgelerde evrensel olabileceğini ya da belirli bir coğrafi bölgeye özgü olabileceğini belirtmişlerdir. Gözübüyük ve ark, (2019) tarımsal üretimin asıl 
amacının minimum maliyetle optimum verim elde etmek ve ayrıca enerjiyi verimli kullanmak olduğunu belirtmişlerdir. Tritikale ve buğday üretiminde enerji verimliliği üzerine yaptıkları çalışmalarında her iki bitki üretiminde de çevreye zararlı yenilenebilir olmayan enerji kullanıldığını ve bu enerjinin büyük miktarının gübre enerjisi ve yakıt enerjisi olduğunu belirtmişlerdir. Toprak yapısı içerisindeki kum, kil, silt değerlerinin toprak sıkışmasına etkisi vardır. Toprak sıkışması verimi düşürmektedir. Kuhwald ve ark, (2008) yaptıkları çalışmada, toprak direncinin toprak tekstürüne, toprak yapısına ve organik karbon içeriğine bağı olduğunu belirtmişlerdir. Baran ve ark, (1996) yaptıkları çalışmada killi tınlı topraklarda organik toprak eklemenin sıkışmaya olan etkisini araştırmışlardır. \% 4 oranında organik toprakla karıştırılmış örneklerde bütün sıkışma düzeylerinde, yarayışlı su miktarları hariç, diğer özelliklerin olumlu yönde etkilendiğini saptamışlardır.

Dünya'nın ve Türkiye'nin neredeyse her bölümünde üretimi yapılan buğday; gerek çok büyük üretici kitlesini ilgilendirmesi, gerekse insanların temel gıdası olan ekmeğin hammaddesini oluşturması bakımından oldukça önemli bir üründür.

Çalışma kapsamında öncelikle Sivas ilinin Gürün ilçesinde buğday üretimi yapan 30 çiftçi belirlenmiştir. Tüik (2018) verilerine göre Türkiye'de 20.000 .000 ton buğday (durum buğdayı + durum buğdayı hariç) üretimi yapılmış olup bunun 624.119 ton'u Sivas ilinde gerçekleşmiştir. Sivas ili Türkiye'deki toplam üretim içerisinde \% 3,12'lik bir paya sahiptir. Çalışmada, buğdayın ekiminden hasadına kadar harcanan enerji miktarının ortalaması ile buna etki edebilecek çevresel faktörler incelenmiş ve bunlar arasındaki ilişki tespit edilmeye çalışılıştır. Çevresel faktörler olarak enerji tüketimine etki edebilecek toprağın yapısı, arazinin taşlık değeri ve arazinin eğimi göz önüne alınmıştır. Bu faktörler uygun bir şekilde düzenlenerek enerji tüketiminin minimum seviyeye getirilmesi hedeflenmektedir. Özellikle yürütülen çalışmalar tarımsal üretimin farklı aşamalarında tüketilen enerji miktarları dikkate alınarak yapılmaktadır. Bununla birlikte enerjiye etki eden fiziksel şartlar göz önüne alınmamıştır. $\mathrm{Bu}$ çalışma enerji ile birlikte enerjiye etki eden arazinin fiziksel şartlarını dikkate alınması ile önem ve farklılık arz etmektedir.

\section{Materyal ve Metot}

\section{Sivas ilinde buğday tarimi yapılan araziler}

Sivas ili Gürün ilçesinde Karadoruk, Kavak, Başören ve Erdoğan köylerinde kuru tarımla buğday üretimi yapan aynı zamanda danışmanlığı yapılan 30 çiftçi belirlendikten sonra buğdayın ilk ekiminden hasadına kadar geçen süre içinde sürekli gözlem yapılarak belirli veriler elde edilmiştir. Buğday üretiminde dekara düşen litre olarak yakıt miktarı belirlenerek, bu değere çevresel faktörlerin ( toprağın yapısı, arazi eğimi, taşlılık oranı) nasıl etki ettiği gözlemlenmiştir. Böylece enerji tüketimine etki eden etmenlerle, enerji tüketimini minimuma indirebilecek uygulamaların araştırılması ve bunların uygulanması sağlanmış olacaktır.

\section{Elek analizi}

Uluslararası sistemde; çapı $2 \mathrm{~mm}$ 'den büyük parçacıklar çakıl-taş, $2 \mathrm{~mm}$ ile $0.02 \mathrm{~mm}$ arası parçalar kum, $0.02 \mathrm{~mm}$ ile $0.002 \mathrm{~mm}$ arası silt ve $0.002 \mathrm{~mm}$ den küçük parçalar kil olarak sınıflandırılmıştır (Anonim, 2019). Elek analizi ile $0.02 \mathrm{~mm}$ çapına kadar olan parçalar hesaplanmaktadır. Elek analizi yöntemi $0.02 \mathrm{~mm}$ çapından büyük parçacıkların ayrıştırmasında kullanılan bir yöntemdir. Eşit aralıkı ve birbiri ile 90 derecelik açı ile kesişen tellerden oluşan bir kare eleği kullanılmıştır.

$\mathrm{Bu}$ analizde $2 \mathrm{~mm}$ ve $0.02 \mathrm{~mm}$ genişliklerinde iki elek kullanılmıştır. Araziden alınan $1 \mathrm{~kg}$ ağırlığındaki numuneyi ilk önce $2 \mathrm{~mm}$ eleğe katıp 15 dakika eledikten sonra eleğin içinde kalan miktar tartılıp not edilmiştir. Daha sonra elekten geçen numuneyi 0.02 mm genişliğinde eleğe katıp 15 dakika eledikten sonra elekte kalan numune ile elekten geçen numune ayrı ayrı tartılıp not edilmiştir. Son olarak alınan verilerin istatistiksel 
analizi yapılıp topraktaki çakıl-taşlık oranı, kum oranı ve kil ile silt oranı bulunmuştur. Silt ve kil oranını belirlemek uzun bir zaman gerektirdiğinden ve ekipman yetersizliğinden ötürü, işlemler toprak analizi laboratuvarlarında gerçekleştirilmiştir. Yapılan toprak analizi sonuçlarına göre topraktaki silt ve kil oranı her arazi için ayrı ayrı belirlenmiştir.

\section{Arazi eğiminin ölçülmesi}

İki nokta arasındaki yükselti farkının bu iki nokta arasındaki yatay uzaklığa oranı ile eğim bulunmaktadır. Yükselti farkını bulmak için, nivo ve mira aletinden faydalanılmıştır. Yatay uzunluk mesafesini bulmak için metre kullanılmıştır. Eğim denklemi aşağıda belirtilmiştir (Anonim, 2018).

Ĕgim $=\frac{\text { yükselti }}{\text { yatay uzunluk }} \times 100$

\section{Istatistik analizleri}

İstatistik analizleri SPSS programı yardımıyla yapılmıştır. İstatistik analizlerinde bağımlı değişken olarak tüketilen enerji, bağımsız değişkenler olarak taşlık değeri, toprak yapısı ve eğim değerleri belirlenmiştir. Toprak yapısı kum, kil ve silt olmak üzere üç değerden oluşmakta ve her bir değerin ayrı ayrı tüketilen enerji değerinde değişimlere katkısı da incelenmiştir. Ön analiz kapsamında tanımlayıcı istatistiksel analiz yapılmıştır. Uygun analiz türünün belirlenmesinde ilk kriter, verilerin türüdür. Veri türüne göre parametrik veya parametrik olmayan testlerden hangisinin yapılacağını belirlemek için Kolmogorov-Smirnov testi yapılmıştır. Testin sonucunda parametrik testlerin uygun olduğu belirlenmiştir. Parametrik testlerden regresyon ve korelasyon analizleri yapılarak bağımlı değişkene (yakıt tüketimi) ve bağımsız değişkenlerin (arazi eğimi, toprak yapısı) hangi oranlarda etki ettiği belirlenmiştir.

\section{Araştırma Bulguları ve Tartışma}

Tarımsal alanlardan elde edilen veriler

Sivas bölgesinde buğday üretimi yapan 30 çiftçi belirlenerek ekimden hasada kadarki süreç içerisinde yapılan tüm işlemler gözlemlenerek araştırma için gerekli olan veriler elde edilmiştir. Elde edilen veriler Çizelge 1'de gösterilmiştir.

\section{Araştırma verilerinin ön analizi}

Çizelge 2'de bağımlı ve bağımsız değişkenlerin istatiksel tanım verileri verilmiştir. 
Çizelge 1. Tarım alanlarından elde edilen veriler

Table 1. Data obtained from agricultural fields

\begin{tabular}{|c|c|c|c|c|c|c|c|c|c|c|c|}
\hline \multirow{2}{*}{$\begin{array}{l}\text { Araziler } \\
\text { Lands }\end{array}$} & \multirow{2}{*}{$\begin{array}{l}\text { Tohum } \\
\text { Çeşidi } \\
\text { Seed } \\
\text { Type }\end{array}$} & \multirow{2}{*}{$\begin{array}{c}\text { Taşlık } \\
\text { Değeri(\%) } \\
\text { Stony } \\
\text { Value (\%) }\end{array}$} & \multicolumn{3}{|c|}{$\begin{array}{l}\text { Toprağın Yapısı(\%) } \\
\text { Structure of Soil } \\
\text { (\%) }\end{array}$} & \multirow{2}{*}{$\begin{array}{c}\text { Eğim( } \alpha) \\
(\%) \\
\text { Slope } \\
(\alpha)(\%)\end{array}$} & \multicolumn{5}{|c|}{$\begin{array}{c}\text { Tüketilen Yakıt Miktarı } \\
\left(\mathrm{I} \mathrm{da} \mathrm{d}^{-1}\right) \\
\text { Amount of Fuel Consumed } \\
\left(\mathrm{l} \mathrm{da} \mathrm{a}^{-1}\right)\end{array}$} \\
\hline & & & $\begin{array}{l}\text { Kum } \\
\text { Sandy }\end{array}$ & $\begin{array}{l}\text { Kil } \\
\text { clay }\end{array}$ & Silt & & $\begin{array}{c}\text { Toprak } \\
\text { Hazırlığı } \\
\text { Soil } \\
\text { Preparation }\end{array}$ & $\begin{array}{l}\text { Ekim } \\
\text { Sowing }\end{array}$ & $\begin{array}{l}\text { İlaçlama } \\
\text { Spraying }\end{array}$ & $\begin{array}{l}\text { Gübreleme } \\
\text { Fertilizing }\end{array}$ & $\begin{array}{c}\text { Toplam } \\
\text { Total }\end{array}$ \\
\hline 1 & $\begin{array}{c}\text { Ankara } \\
98\end{array}$ & 48 & 60 & 18 & 22 & 23 & 2.0 & 1.9 & 1.1 & 1.0 & 6.0 \\
\hline 2 & $\begin{array}{c}\text { Ankara } \\
98\end{array}$ & 28 & 41 & 37 & 22 & 43 & 2.2 & 2.0 & 1.2 & 1.1 & 6.5 \\
\hline 3 & $\begin{array}{c}\text { Ankara } \\
98\end{array}$ & 63 & 52 & 31 & 17 & 46 & 2.3 & 2.2 & 1.1 & 1.2 & 6.8 \\
\hline 4 & Bayraktar & 28 & 40 & 33 & 27 & 17 & 1.7 & 1.6 & 0.9 & 0.8 & 5.0 \\
\hline 5 & Bayraktar & 22 & 40 & 37 & 23 & 9 & 1.5 & 1.4 & 0.8 & 0.7 & 4.4 \\
\hline 6 & $\begin{array}{c}\text { Ankara } \\
98\end{array}$ & 48 & 45 & 33 & 22 & 47 & 2.4 & 2.3 & 1.5 & 1.4 & 7.6 \\
\hline 7 & Bayraktar & 18 & 38 & 35 & 27 & 36 & 1.8 & 1.7 & 0.9 & 1.0 & 5.4 \\
\hline 8 & Ankara 98 & 23 & 42 & 38 & 20 & 27 & 1.6 & 1.5 & 0.9 & 0.8 & 4.8 \\
\hline 9 & Ankara 98 & 27 & 45 & 40 & 15 & 42 & 1.7 & 1.6 & 0.9 & 0.8 & 5.0 \\
\hline 10 & Odeska & 68 & 56 & 23 & 21 & 56 & 1.9 & 1.8 & 1.0 & 0.9 & 5.6 \\
\hline 11 & Bayraktar & 51 & 43 & 37 & 20 & 22 & 1.8 & 1.7 & 0.8 & 0.9 & 5.2 \\
\hline 12 & Kızıltan & 28 & 37 & 41 & 22 & 20 & 1.7 & 1.6 & 0.8 & 0.9 & 5.0 \\
\hline 13 & Odeska & & 27 & 52 & 21 & 11 & 1.9 & 1.8 & 0.9 & 1.0 & 5.6 \\
\hline 14 & Ankara 98 & 17 & 32 & 43 & 25 & 18 & 1.4 & 1.3 & 0.8 & 0.7 & 4.2 \\
\hline 15 & Ankara 98 & 48 & 47 & 33 & 20 & 16 & 1.5 & 1.4 & 0.8 & 0.7 & 4.4 \\
\hline 16 & Bayraktar & 22 & 37 & 43 & 20 & 13 & 1.5 & 1.5 & 0.7 & 0.8 & 4.5 \\
\hline 17 & Bayraktar & 23 & 38 & 33 & 29 & 14 & 1.6 & 1.5 & 0.9 & 0.8 & 4.8 \\
\hline 18 & Bayraktar & 48 & 30 & 43 & 27 & 12 & 1.4 & 1.3 & 0.8 & 0.7 & 4.2 \\
\hline 19 & Bayraktar & 23 & 32 & 43 & 25 & 32 & 1.7 & 1.6 & 0.9 & 0.8 & 5.0 \\
\hline 20 & Bayraktar & 13 & 27 & 46 & 27 & 7 & 1.5 & 1.4 & 0.8 & 0.7 & 4.4 \\
\hline 21 & Bayraktar & 23 & 32 & 47 & 21 & 23 & 1.7 & 1.6 & 0.9 & 0.8 & 5.0 \\
\hline 22 & Bayraktar & 38 & 43 & 31 & 26 & 47 & 1.8 & 1.7 & 1.0 & 0.9 & 5.4 \\
\hline 23 & Bayraktar & 17 & 36 & 41 & 23 & 8 & 1.6 & 1.5 & 0.8 & 0.7 & 4.6 \\
\hline 24 & Bayraktar & 43 & 40 & 39 & 21 & 27 & 1.7 & 1.6 & 0.9 & 0.8 & 5.0 \\
\hline 25 & Bayraktar & 48 & 43 & 36 & 21 & 43 & 1.8 & 1.7 & 1.0 & 0.9 & 5.4 \\
\hline 26 & Bayraktar & 46 & 43 & 36 & 21 & 9 & 1.5 & 1.4 & 0.8 & 0.7 & 4.4 \\
\hline 27 & Bayraktar & 43 & 44 & 36 & 20 & 37 & 1.7 & 1.6 & 0.9 & 0.8 & 5.0 \\
\hline 28 & Bayraktar & 28 & 32 & 30 & 28 & 6 & 1.5 & 1.4 & 0.8 & 0.7 & 4.4 \\
\hline 29 & Bayraktar & 16 & 33 & 38 & 29 & 42 & 2.2 & 2.1 & 1.3 & 1.2 & 6.8 \\
\hline 30 & Bayraktar & 8 & 34 & 36 & 30 & 7 & 1.8 & 1.7 & 0.9 & 0.8 & 5.2 \\
\hline
\end{tabular}

Çizelge 2 her bir değişkenin yalın hallerinin basit bir şekilde incelendiği tablodur. Çizelge 2'de tüketilen enerji değerinin minimum değeri 4.2 , maksimum değeri 7.6 ve ortalama tüketilen enerji ise $5.187^{\prime}$ dir. Ortalama arazi eğimi $25.33^{\prime}$ tür.
Ortalama kum değerinin 39.97, ortalama silt değerinin 23.07 ve ortalama kil değerinin ise 36.97 olduğu görülmektedir. Arazilerin minimum, maksimum ve ortalama taşık değerleri sırasıyla; 8.68 ve 32.47 olarak belirlenmiştir. 
Çizelge 2. Tanımlayıcı istatistikler

Table 2. Descriptive statistics

\begin{tabular}{|l|c|c|c|c|c|c|c|c|}
\hline & $\mathrm{N}$ & $\begin{array}{c}\text { Değişim } \\
\text { aralığı } \\
\text { Range }\end{array}$ & Minimum & $\begin{array}{c}\text { Maksimum } \\
\text { Maximum }\end{array}$ & $\begin{array}{c}\text { Ortalama } \\
\text { Mean }\end{array}$ & $\begin{array}{c}\text { Standart } \\
\text { hata } \\
\text { Std. Error }\end{array}$ & $\begin{array}{c}\text { Standart } \\
\text { sapma } \\
\text { Std. } \\
\text { deviation }\end{array}$ & $\begin{array}{c}\text { Varyans } \\
\text { Variance }\end{array}$ \\
\hline $\begin{array}{l}\text { Tüketilen } \\
\text { enerji } \\
\text { Energy } \\
\text { consumed }\end{array}$ & 30 & 3.4 & 4.2 & 7.6 & 5.187 & 0.1527 & 0.8336 \\
\hline $\begin{array}{l}\text { Taşlık değeri } \\
\text { Stony value }\end{array}$ & 30 & 60 & 8 & 68 & 32.47 & 2.839 & 15.551 & 241.844 \\
\hline $\begin{array}{l}\text { Eğim } \\
\text { Slope }\end{array}$ & 30 & 50 & 6 & 56 & 25.33 & 2.752 & 15.075 & 227.264 \\
\hline $\begin{array}{l}\text { Kum } \\
\text { Sandy }\end{array}$ & 30 & 33 & 27 & 60 & 39.97 & 1.405 & 7.695 & 59.206 \\
\hline $\begin{array}{l}\text { Kil } \\
\text { Clay }\end{array}$ & 30 & 34 & 18 & 52 & 36.97 & 1.244 & 6.815 & 46.447 \\
\hline Silt & 30 & 15 & 15 & 30 & 23.07 & 0.678 & 3.713 & 13.789 \\
\hline
\end{tabular}

Kolmogorov-Smirnov Testi (Normal dağılıma uygunluk testi)

Örneklem büyüklüğümüz 30 (yeterli) olduğu için verilerimizin normal dağılıp dağılmadığı incelenmiş ve sonrasında hangi test grubunun kullanılacağı belirlenmiştir. Yapılan incelemelerde parametrik analizlerin yapılması gerektiği kanaatine varılmıştır. Eğer veriler rassal dağılmıyor ise yanlı sonuçlar almamak amacıyla parametrik olmayan veriler için testlere yönelmek gerekecektir. Çizelge 3'te Kolmogorov-Smirnov testi sonuçları verilmiştir.

Çizelge 3. Kolmogorov-Smirnov testi sonuçları

Table 3. Kolmogorov-Smirnov test results

\begin{tabular}{|c|c|c|c|c|c|c|}
\hline \multicolumn{7}{|c|}{$\begin{array}{l}\text { Kolmogorov-Smirnov Testi } \\
\text { Kolmogorov-Smirnov Test }\end{array}$} \\
\hline & $\begin{array}{l}\text { Tüketilen enerji } \\
\text { Energy consumed }\end{array}$ & $\begin{array}{l}\text { Taşlık değeri } \\
\text { Stony value }\end{array}$ & $\begin{array}{l}\text { Eğim } \\
\text { Slope }\end{array}$ & $\begin{array}{l}\text { Kum } \\
\text { Sandy }\end{array}$ & $\begin{array}{l}\text { Kil } \\
\text { Clay }\end{array}$ & Silt \\
\hline $\begin{array}{l}\text { Asymp. Sig. (2- } \\
\text { tailed) }\end{array}$ & $0.258^{c}$ & $0.101^{\mathrm{c}}$ & $0.191^{c}$ & $0.200^{c, d}$ & $0.200^{c, d}$ & $0.065^{c}$ \\
\hline \multicolumn{3}{|c|}{$\begin{array}{l}\text { a. Test dağılımı normal } \\
\text { a. Test distribution normal }\end{array}$} & \multicolumn{2}{|c|}{$\begin{array}{l}\text { c. Lilliefors anlamlılık } \\
\text { düzeltmesi } \\
\text { c. Lilliefors significance } \\
\text { correction }\end{array}$} & \multicolumn{2}{|c|}{$\begin{array}{l}\text { d. Gerçek öneme sahip bir alt } \\
\text { sınırdır. } \\
\text { d. This is a lower bound of } \\
\text { the true significance }\end{array}$} \\
\hline
\end{tabular}

Çizelge 3'de Kolmogorov-Smirnov testi sonuçları verilmiştir. Tablonun Assymp.Sig. (Anlamlılık) satırındaki değerlerin istatistiksel anlamlılık hesaplamalarında sınır değeri kabul edilen 0.05 'ten büyük olması incelenen faktörlerin dağılımlarının normal olduğunu göstermektedir. Eğer bu değerlerin 0.05 ten küçük olması durumunda parametrik olmayan test yöntemlerinin kullanılması gerekmektedir.

\section{ikili regresyon analizi}

îkili regresyon analizi bağımsız değişken hakkında sahip olunan bilgiler ile bağımlı değişkenin tahmin edilmesini sağlayan bir analizdir. Her bir veri için ayrı ayrı inceleme yapılmıştır.

Bağımlı değişken tüketilen enerji ile bağımsız değişken taşlık değeri arasındaki model özeti ve varyans analizi Çizelge 4'te verilmiştir. 
Çizelge 4. Arazi taşlık değeri ile tüketilen enerji arasındaki ilişki

Table 4. The relation between the stony value of the land and the energy consumed

\begin{tabular}{|c|c|c|c|c|c|c|}
\hline \multicolumn{7}{|c|}{$\begin{array}{l}\text { Model Özeti } \\
\text { Model Summary }\end{array}$} \\
\hline Model & $\mathrm{R}$ & $\mathrm{R}^{2}$ & $\begin{array}{l}\text { Düzeltilmiş } \mathrm{R}^{2} \\
\text { Adjusted } R^{2}\end{array}$ & \multicolumn{3}{|c|}{$\begin{array}{l}\text { Tahminin standart hatası } \\
\text { Std. Error of the estimate }\end{array}$} \\
\hline 1 & $0.284^{\mathrm{a}}$ & 0.80 & 0.48 & \multicolumn{3}{|c|}{0.8164} \\
\hline \multicolumn{7}{|c|}{$\begin{array}{l}\text { a. Belirleyiciler: (Sabit), Taşlık değeri } \\
\text { a. Predictors: (Constant), Stony value }\end{array}$} \\
\hline \multicolumn{7}{|c|}{$\begin{array}{c}\left.\text { Varyans Analizi (Anova }{ }^{\mathrm{a}}\right) \\
\text { Analysis of Variance }\left(\text { Anova }^{\mathrm{a}}\right)\end{array}$} \\
\hline Model & $\begin{array}{l}\text { Kareler toplamı } \\
\text { Sum of squares }\end{array}$ & $\begin{array}{l}\text { Serbestlik derecesi } \\
\text { Degree of freedom }\end{array}$ & \multicolumn{2}{|c|}{$\begin{array}{c}\text { Ortalama kare } \\
\text { Mean square }\end{array}$} & $\mathrm{F}$ & $\mathrm{p}$ \\
\hline $\begin{array}{l}\text { Regresyon } \\
\text { Regression }\end{array}$ & 1.632 & 1 & \multicolumn{2}{|l|}{1.632} & 2.449 & $0.129^{b}$ \\
\hline \multicolumn{3}{|c|}{$\begin{array}{l}\text { a. Bağımlı değişken: Tüketilen enerji değeri } \\
\text { a. Dependent variable: Energy consumed value }\end{array}$} & \multicolumn{3}{|c|}{$\begin{array}{l}\text { b. Belirleyici (Sabit): Taşlık } \\
\text { b. Predictors: (Constant): Stony }\end{array}$} & \\
\hline
\end{tabular}

Çizelge 4'de arazi taşlık değeri ile tüketilen enerji arasındaki analiz sonuçları verilmiştir. Bağımsız değişken olan taşlık değerinin tek başına, bağımlı değişken olan tüketilen enerji değişkenini \%8 oranında açıkladığı görülmektedir. Diğer bir ifade ile tüketilen enerji miktarı \%8 oranında arazinin taşlık değerine bağlıdır. $p$ değeri (sig) $=0.129>0.05$ hesaplandığı için HO (İstatistiksel olarak anlamlı bir farklılık yoktur) hipotezi kabul edilmiştir. ANOVA tablosunun anlamlılık sütunundaki değer, söz konusu değişkenler arasındaki ilişkinin 0.05 düzeyinde istatistiksel olarak anlamlı olmadığı belirlenmiştir. Tek başına taşlık değeri tüketilen enerji miktarını açıklayamamaktadır.

Bağımlı değişken tüketilen enerji ile bağımsız değişken eğim arasındaki model özeti ve varyans analizi Çizelge 5 'de verilmiştir.

Çizelge 5. Arazi eğimi ile tüketilen enerji ilişkisi

Table 5. Relation of energy consumed with land slope

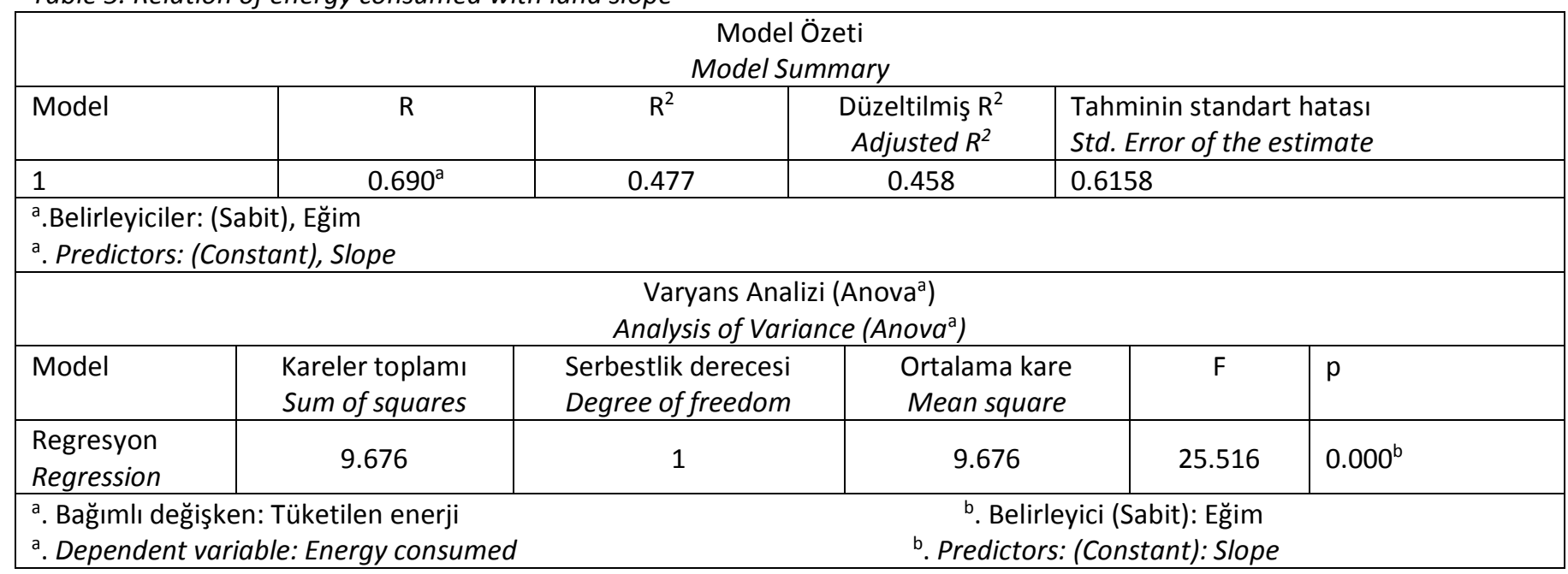

Çizelge 5'de arazinin eğimi, tüketilen enerji değişkenini tek başına \%47 oranında açıklamaktadır. Yani tüketilen enerji miktarının arazinin eğimine yüksek oranda bağımlı olduğunu göstermektedir. Arazi eğiminin tek başına tüketilen enerji üzerindeki etkisinin yüksek olması, arazi eğiminin üzerinde durulması gereken birincil konulardan birisi olduğu belirlenmiştir. (Sig) p $<0.05$ olduğu için ilişki rastlantısal değildir, istatistiksel olarak anlamlıdır. Eğimin tüketilen enerji ile olan ilişkisi için yapılacak yorumlar anlamlıdır.

Bağımlı değişken tüketilen enerji ile bağımsız değişken kum arasındaki model özeti ve varyans analizi Çizelge 6'da verilmiştir. 
Çizelge 6. Toprak yapısındaki kum değeri ile tüketilen enerji ilişkisi

Table 6. Relation of energy consumed with sand value in soil structure

\begin{tabular}{|c|c|c|c|c|c|c|}
\hline \multicolumn{7}{|c|}{$\begin{array}{c}\text { Model Özeti } \\
\text { Model Summary }\end{array}$} \\
\hline Model & $\mathrm{R}$ & \begin{tabular}{l|l}
$\mathrm{R}^{2}$ &
\end{tabular} & $\begin{array}{l}\text { Düzeltilmiş } \mathrm{R}^{2} \\
\text { Adjusted } R^{2}\end{array}$ & \multicolumn{3}{|c|}{$\begin{array}{l}\text { Tahminin standart hatası } \\
\text { Std. Error of the estimate }\end{array}$} \\
\hline 1 & $0.346^{\mathrm{a}}$ & 0.120 & 0.088 & \multicolumn{3}{|c|}{0.7988} \\
\hline \multicolumn{7}{|c|}{$\begin{array}{l}\text { a.Belirleyiciler: (Sabit), Kum } \\
\text { a. Predictors: (Constant), Sandy }\end{array}$} \\
\hline \multicolumn{7}{|c|}{$\begin{array}{c}\left.\text { Varyans Analizi (Anova }{ }^{\mathrm{a}}\right) \\
\text { Analysis of Variance }\left(\text { Anova }^{\mathrm{a}}\right)\end{array}$} \\
\hline Model & $\begin{array}{l}\text { Kareler toplamı } \\
\text { Sum of squares }\end{array}$ & $\begin{array}{l}\text { Serbestlik derecesi } \\
\text { Degree of freedom }\end{array}$ & \multicolumn{2}{|c|}{$\begin{array}{l}\text { Ortalama kare } \\
\text { Mean square }\end{array}$} & $\mathrm{F}$ & $\mathrm{p}$ \\
\hline $\begin{array}{l}\text { Regresyon } \\
\text { Regression }\end{array}$ & 2.430 & 1 & \multicolumn{2}{|l|}{2.430} & 3.808 & $0.061^{b}$ \\
\hline \multicolumn{7}{|c|}{ a. Bağımlı değişken: Tüketilen enerji } \\
\hline
\end{tabular}

Çizelge $6^{\prime}$ da toprak yapısındaki kum değeri ile tüketilen enerji bağıntısına bakıldığında tek başına kum değeri tüketilen enerjideki değişimleri \%12 oranında açıklamaktadır. Anova testine bakıldığında, $\quad p>0.05$ olduğu için ilişki rastlantısaldır denilebilir. Tek başına kum değeri ile tüketilen enerjiyi açıklamak doğru olmayacaktır.

Bağımlı değişken tüketilen enerji ile bağımsız değişken silt arasındaki model özeti ve varyans analizi Çizelge 7'de verilmiştir.

Çizelge 7. Toprak yapısındaki silt değeri ile tüketilen enerji ilişkisi

Table 7. Relation of energy consumed with silt value in soil structure

\begin{tabular}{|c|c|c|c|c|c|c|}
\hline \multicolumn{7}{|c|}{$\begin{array}{l}\text { Model Özeti } \\
\text { Model Summary }\end{array}$} \\
\hline Model & $\mathrm{R}$ & \begin{tabular}{l|l} 
& $R^{2}$
\end{tabular} & $\begin{array}{l}\text { Düzeltilmiş } R^{2} \\
\text { Adjusted } R^{2}\end{array}$ & \multicolumn{3}{|c|}{$\begin{array}{l}\text { Tahminin standart hatası } \\
\text { Std. Error of the estimate }\end{array}$} \\
\hline 1 & $0.126^{a}$ & 0.16 & -0.019 & \multicolumn{3}{|c|}{0.8445} \\
\hline \multicolumn{7}{|c|}{$\begin{array}{l}\text { a. Belirleyiciler: (Sabit), Silt } \\
\text { a.Predictors: (Constant), Silt }\end{array}$} \\
\hline \multicolumn{7}{|c|}{$\begin{array}{l}\text { Varyans Analizi }\left(\text { Anova }^{\mathrm{a}}\right) \\
\text { Analysis of Variance }\left(\text { Anova }^{\mathrm{a}}\right)\end{array}$} \\
\hline Model & $\begin{array}{l}\text { Kareler toplamı } \\
\text { Sum of squares }\end{array}$ & $\begin{array}{l}\text { Serbestlik derecesi } \\
\text { Degree of freedom }\end{array}$ & $\begin{array}{l}\text { Ortalama I } \\
\text { Mean squ }\end{array}$ & & $\mathrm{F}$ & $p$ \\
\hline $\begin{array}{l}\text { Regresyon } \\
\text { Regression }\end{array}$ & 0.323 & 1 & 0.323 & & 0.454 & $0.506^{b}$ \\
\hline \multicolumn{7}{|c|}{ 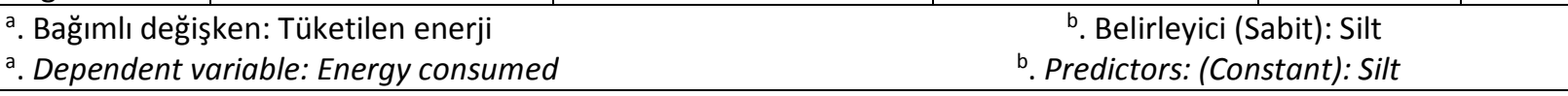 } \\
\hline
\end{tabular}

Çizelge 7'de toprak yapısındaki silt değeri ile tüketilen enerji bağıntısına bakıldığında silt değeri tek başına tüketilen enerjiyi \%1 oranında açıklamaktadır. Varyans analizinde $p>0.05$ olduğu için ilişki rastlantısaldır denilebilir. Tek başına silt değeri ile tüketilen enerjiyi açıklamak doğru olmayacaktır.

Bağımlı değişken tüketilen enerji ile bağımsız değişken kil arasındaki model özeti ve varyans analizi Çizelge 8'de verilmiştir. 
Çizelge 8. Toprak yapısındaki kil değeri ile tüketilen enerji ilişkisi

Table 8. Relation of energy consumed with clay value in soil structure

\begin{tabular}{|c|c|c|c|c|c|c|}
\hline \multicolumn{7}{|c|}{$\begin{array}{l}\text { Model Özeti } \\
\text { Model Summary }\end{array}$} \\
\hline Model & $\mathrm{R}$ & \begin{tabular}{l|l}
$R^{2}$ &
\end{tabular} & $\begin{array}{l}\text { Düzeltilmiş } \mathrm{R}^{2} \\
\text { Adjusted } R^{2}\end{array}$ & \multicolumn{3}{|c|}{$\begin{array}{l}\text { Tahminin standart hatası } \\
\text { Std. Error of the estimate }\end{array}$} \\
\hline 1 & $0.322^{\mathrm{a}}$ & 0.104 & 0.072 & \multicolumn{3}{|c|}{0.8061} \\
\hline \multicolumn{7}{|c|}{$\begin{array}{l}\text { a. Belirleyiciler: (Sabit), Kil } \\
\text { a.Predictors: (Constant), Clay }\end{array}$} \\
\hline \multicolumn{7}{|c|}{$\begin{array}{c}\text { Varyans Analizi (Anova }{ }^{\mathrm{a}} \text { ) } \\
\text { Analysis of Variance (Anovaa) }\end{array}$} \\
\hline Model & $\begin{array}{l}\text { Kareler toplamı } \\
\text { Sum of squares }\end{array}$ & $\begin{array}{l}\text { Serbestlik derecesi } \\
\text { Degree of freedom }\end{array}$ & \multicolumn{2}{|c|}{$\begin{array}{l}\text { Ortalama kare } \\
\text { Mean square }\end{array}$} & $\mathrm{F}$ & $p$ \\
\hline $\begin{array}{l}\text { Regresyon } \\
\text { Regression }\end{array}$ & 2.102 & 1 & \multicolumn{2}{|l|}{2.102} & 3.236 & $0.083^{b}$ \\
\hline \multicolumn{7}{|c|}{ a. Bağımlı değişken: Tüketilen enerji } \\
\hline
\end{tabular}

Çizelge 8'deki toprak yapısındaki kil değeri ile tüketilen enerji bağıntısına bakıldığında kil değeri tek başına tüketilen enerjiyi $\% 10$ oranında açıklamaktadır. Kayhan ve ark, (2013) yaptıkları çalışmada, topraktaki kil düzeyinin artışının toprakta sıkışmaya etki ettiğini ve sıkışmanın da hacim ağırlığını arttırırken poroziteyi azalttığını belirtmişlerdir. Çizelge 8'teki anova testine bakıldığında $\quad p>0.05 \quad$ olduğu için ilişki rastlantısaldır. Tek başına kil değeri ile tüketilen enerjiyi açıklamak doğru olmayacaktır.

Çizelge 9. Çoklu regresyon analizi sonuçları

Table 9. Multiple regression analysis results

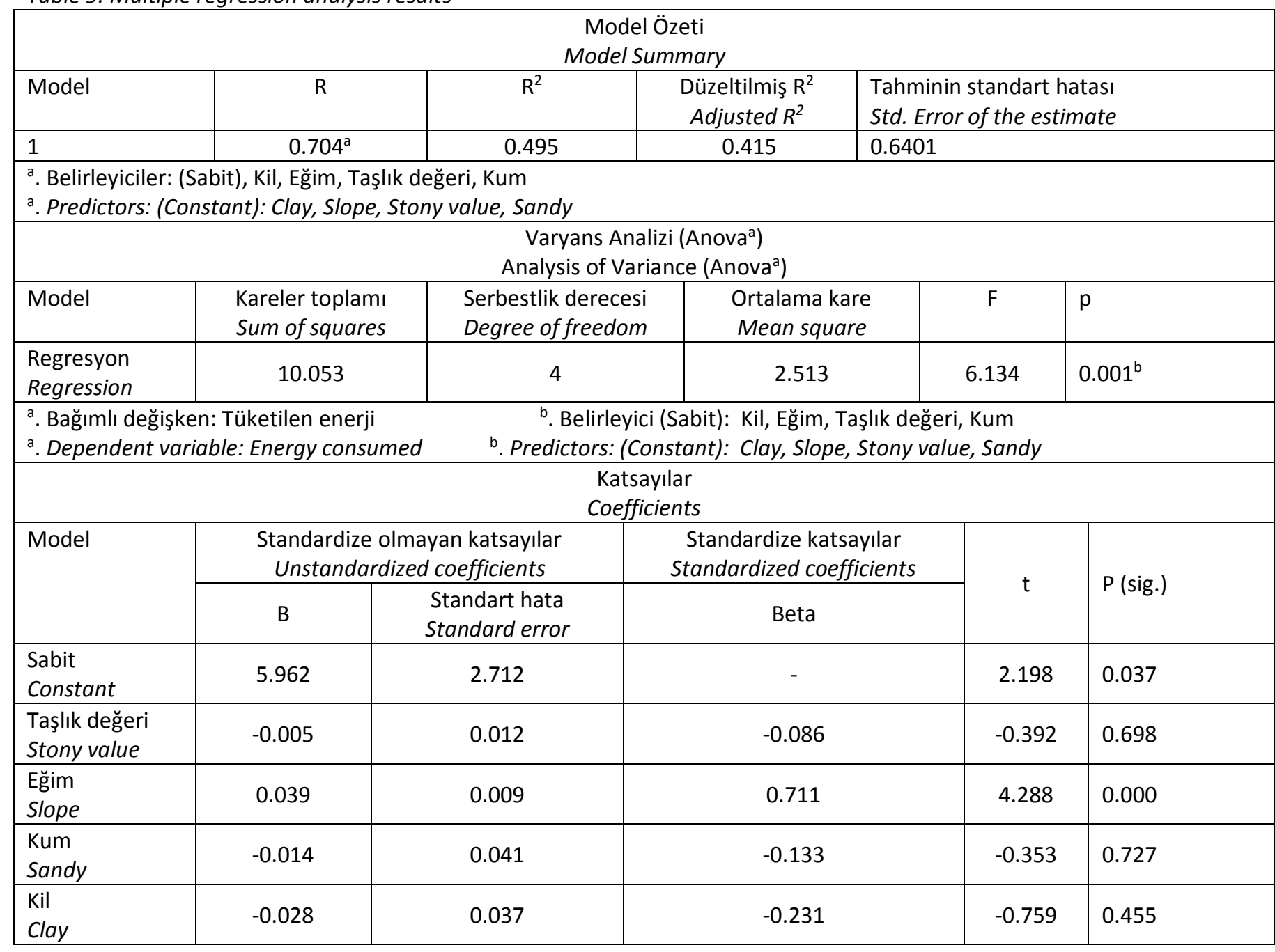




\section{Çoklu regresyon analizi}

Regresyon analizi, bir veya birden daha fazla bağımsız değişkenin, bağımlı bir değişkenle arasındaki ilişkiyi matematiksel bir denklem olarak ortaya koymak için kullanılmaktadır. Çoklu regresyonda tek bağımsız değişken yerine bağımsız değişkenlerinin tamamı ile olan ilişkisine bakılmaktadır. Modelin yani tezin ana konusu bu test ile açıklanmıştır. Modelin anlamlılık düzeyi de çoklu regresyon analizi ile belli olmuştur. Tüketilen enerji ile diğer veriler arasındaki çoklu regresyon analizi sonuçları Çizelge 9'da verilmiştir.

Çizelge 9'daki modelde bağımsız değişkenlerin (arazi taşlık değeri, arazi toprak yapısı ve arazi eğimi) bağımlı değişken durumundaki tüketilen enerji değişkenine ait varyansı \% 49.5 oranında açıkladığı, diğer bir ifade ile tüketilen enerjinin \% 70 oranında bu faktörlere bağlı olarak şekillendiği anlaşılmaktadır. Değişkenler arasındaki ilişkiyi belirlemek için çoklu regresyon anova testi ve çoklu regresyon katsayı tablosu beraber incelenmiştir.

Çizelge 9'daki ANOVA tablosunun anlamlılık sütunundaki değere bakılarak söz konusu değişkenler arasındaki ilişkinin $p<0.05$ düzeyinde istatistiksel olarak anlamlı olduğu görülmektedir.

Çizelge 10. Korelasyon analizi sonuçları

Table 10. Correlation analysis results

\begin{tabular}{|c|c|c|c|}
\hline \multicolumn{4}{|c|}{$\begin{array}{l}\text { Tüketilen enerji ile taşlık değeri arasındaki korelasyon analizi } \\
\text { Correlation analysis between energy consumed and stony value }\end{array}$} \\
\hline & & $\begin{array}{l}\text { Tüketilen enerji } \\
\text { Energy consumed }\end{array}$ & $\begin{array}{l}\text { Taşlık değeri } \\
\text { Stony value }\end{array}$ \\
\hline \multirow{3}{*}{$\begin{array}{l}\text { Tüketilen enerji } \\
\text { Energy consumed }\end{array}$} & $\begin{array}{l}\text { Pearson korelasyonu } \\
\text { Pearson correlation }\end{array}$ & 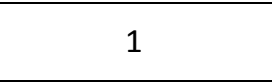 & 0.284 \\
\hline & Sig. (2-tailed) & - & 0.129 \\
\hline & $\mathrm{N}$ & 30 & 30 \\
\hline \multicolumn{4}{|c|}{$\begin{array}{l}\text { Tüketilen enerji ile arazi eğimi arasındaki korelasyon analizi } \\
\text { Correlation analysis between energy consumed and land slope }\end{array}$} \\
\hline & & $\begin{array}{l}\text { Tüketilen enerji } \\
\text { Energy consumed }\end{array}$ & $\begin{array}{l}\text { Arazi eğimi } \\
\text { Land slope }\end{array}$ \\
\hline \multirow{3}{*}{$\begin{array}{l}\text { Tüketilen enerji } \\
\text { Energy consumed }\end{array}$} & $\begin{array}{l}\text { Pearson korelasyonu } \\
\text { Pearson correlation }\end{array}$ & 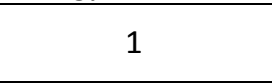 & $0.690^{* *}$ \\
\hline & Sig. (2-tailed) & - & 0.000 \\
\hline & $\mathrm{N}$ & 30 & 30 \\
\hline \multicolumn{4}{|c|}{$\begin{array}{l}\text { Tüketilen enerji ile kum miktarı arasındaki korelasyon analizi } \\
\text { Correlation analysis between energy consumed and the amount of sand }\end{array}$} \\
\hline & & $\begin{array}{l}\text { Tüketilen enerji } \\
\text { Energy consumed }\end{array}$ & $\begin{array}{l}\text { Kum } \\
\text { Sand }\end{array}$ \\
\hline \multirow{3}{*}{$\begin{array}{l}\text { Tüketilen enerji } \\
\text { Energy consumed }\end{array}$} & $\begin{array}{l}\text { Pearson korelasyonu } \\
\text { Pearson correlation }\end{array}$ & 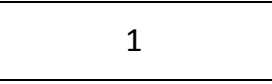 & 0.346 \\
\hline & Sig. (2-tailed) & - & 0.061 \\
\hline & $\mathrm{N}$ & 30 & 30 \\
\hline \multicolumn{4}{|c|}{$\begin{array}{l}\text { Tüketilen enerji ile kil miktarı arasındaki korelasyon analizi } \\
\text { Correlation analysis between energy consumed and theamount of clay }\end{array}$} \\
\hline & & $\begin{array}{l}\text { Tüketilen enerji } \\
\text { Energy consumed }\end{array}$ & $\begin{array}{l}\text { Kil } \\
\text { Clay }\end{array}$ \\
\hline \multirow{3}{*}{$\begin{array}{l}\text { Tüketilen enerji } \\
\text { Energy consumed }\end{array}$} & $\begin{array}{l}\text { Pearson korelasyonu } \\
\text { Pearson correlation }\end{array}$ & 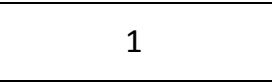 & -0.322 \\
\hline & Sig. (2-tailed) & - & 0.083 \\
\hline & $\mathrm{N}$ & 30 & 30 \\
\hline \multicolumn{4}{|c|}{$\begin{array}{l}\text { Tüketilen enerji ile silt miktarı arasındaki korelasyon analizi } \\
\text { Correlation analysis between energy consumed and the amount of silt }\end{array}$} \\
\hline & & $\begin{array}{l}\text { Tüketilen enerji } \\
\text { Energy consumed }\end{array}$ & Silt \\
\hline \multirow{3}{*}{$\begin{array}{l}\text { Tüketilen enerji } \\
\text { Energy consumed }\end{array}$} & $\begin{array}{l}\text { Pearson korelasyonu } \\
\text { Pearson correlation }\end{array}$ & 1 & -0.126 \\
\hline & Sig. (2-tailed) & - & 0.506 \\
\hline & $\mathrm{N}$ & 30 & 30 \\
\hline \multicolumn{4}{|c|}{$\begin{array}{l}{ }^{* *} . \text { Korelasyon } 0.01 \text { düzeyinde önemlidir } \\
{ }^{* *} \text {. Correlation is significant at the } 0.01 \text { level }\end{array}$} \\
\hline
\end{tabular}


Çizelge 9'daki katsayılar tablosu incelendiğinde, tüketilen enerji miktarını en fazla eğimin etkilediği görülmektedir. Eğim arttıkça tüketilen enerji miktarı 0.04 katsayısı (\%4 oranda) ile artmaktadır. Diğer değişkenlerde ise negatif bir katsayı olduğu, yani ters bir ilişki olduğu görünmektedir. Örnek olarak taşlık değerinin artması tüketilen enerjiyi azalttığı sonucu çıkmaktadır. Fakat sig.>0.05 olduğu için bu taşlık değeri ile ilgili yapılacak yorumlar anlamsız olmaktadır.

\section{Korelasyon analizi}

Korelasyon analizi ile iki farklı değişken arasındaki ilişkinin yönü ve şiddeti hakkında bilgi edinilmiştir. Korelasyon analizi tüketilen enerji ile diğer her bir veri için ayrı ayrı yapılmıştır. Tüketilen enerji ile taşlık değeri arasındaki korelasyon analizi sonuçları Çizelge $10^{\prime} \mathrm{da}$ gösterilmiştir.

Çizelge 10'daki tüketilen enerji ile taşlık değeri arasındaki korelasyona bakıldığında, pozitif doğrusal bir ilişki olduğu görülmektedir. Neden sonuç ilişkisi olmamakla birlikte 0.284 katsayısı ile taşlık değeri arttıkça tüketilen enerjinin artacağı gözlemlenmiştir.

Çizelge 10'daki arazi eğimi ile tüketilen enerji miktarını korelasyon analizine göre incelendiğinde aralarında oldukça güçlü pozitif bir ilişki olduğu görülmektedir. 0.690 oranında eğim arttıkça tüketilen enerjide de artış görüleceği belirlenmiştir.

Çizelge 10'daki korelasyon analizine bakıldığında toprak yapısındaki kum miktarı ile tüketilen enerji miktarı arasında pozitif bir ilişki olduğu görülmektedir. 0.346 katsayısı ile topraktaki kum miktarı arttıkça tüketilen enerjide de artış görüleceği belirlenmiştir.

Çizelge $10^{\prime}$ daki topraktaki kil miktarı ile tüketilen enerji incelendiğinde aralarında negatif yönlü bir ilişki olduğu gözlemlenmektedir. Verilere göre topraktaki kil miktarı arttıkça tüketilen enerji azalmaktadır. Özellikle toprak sıkışmasının yakıt tüketimini arttırdığı bilinmektedir. Demiralay ve ark, (1979) tarafından Erzurum Ovasından alınan 40 toprak örneği üzerindeki çalışmasında topraktaki kil, organik madde ve kireç miktarının sıkışabilirliği azalttığı, silt miktarının etki etmediğini ve kum miktarı arttıkça sıkışabilirliğinin arttığını tespit etmişlerdir. Geri kalan yüzdelik dilimin ise traktör gücü, traktör modeli, yakıt kalitesi vb. etmenlere ait olduğu belirlenmiştir.

Çizelge $10^{\prime}$ daki analize göre topraktaki silt miktarı ile tüketilen enerji arasında negatif yönlü güçlü olmayan bir ilişki bulunmaktadır.

\section{Sonuçlar}

Tarımda tüketilen yakıt enerjisine etki eden sebeplerin araştırıldığı çalışma sonuçlarına göre, tüketilen yakıta etki eden en büyük etmenlerin sırasıyla arazi eğimi (\%47), arazi taşlık değeri (\%8) ve toprak yapısı (\%12 kum, \%10 kil, \%1 silt) olduğu belirlenmiştir.

Yakıt sarfını düşürmek için, tüketilen yakıta en fazla etki eden eğim şartlarını mümkün olduğunca azaltmak, tesviye yapılabilecek yerlerde tesviyenin yapılıp arazi eğimini azaltmak, taş toplama makinası ile toprak taşlık değeri azaltmak, toprak yapısı iyileştirmek için organik gübre takviyesi yapıp kum-kil oranı dengelemeye çalışmak önerilebilir. Bu önerilerin sonucu o yıl için etki etmese de 3 ile 5 yıl sonra sonucu olumlu olarak görülmesi mümkündür.

Tüketilen yakıta etki eden diğer bir faktör traktör gücünün yüksek olmasıdır. Yüksek güç üreten traktör yerine, işin görülebileceği minimum güçte traktör kullanılması, daha tasarruflu traktörlerin tercih edilmesi, kaliteli yakıtın kullanılması gibi, yapılması o sene için mümkün olan ve sonucu görünen önlemlerin alınarak yakıtı daha verimli bir şekilde kullanmak mümkün olabilir.

Doğrudan anıza ekim makinası ile ekimin yapılması, organik tarım yapmak, iyi tarım yöntemleri gibi tarımsal uygulamalar ile üretim esnasında ekipman yoğunluğunu minimize ederek, yakıtı daha verimli kullanma seçenekleri dikkate alınabilir.

\section{Kaynaklar}

Afshar, R. K., Alipour, A., Hashemi, M., Jovini, M. A., \& Pimentel, D. (2013). Energy inputs-yield relationship 
and sensitivity analysis of pistachio (Pistacia vera L.) production in Markazi Region of Iran. Spanish Journal of Agricultural Research, 11(3), 661-669.

Alipour, A., Veisi, H., Darijani, F., Mirbagheri, B., \& Behbahani, A. G. (2012). Study and determination of energy consumption to produce conventional rice of the Guilan province. Research in Agricultural Engineering (RAE), 58(3), 99-106.

Altuntaş, E., Bulut, O. N., \& Özgöz, E. (2019). Kuru tarımda farklı toprak işleme sistemleri ile buğday üretiminin enerji kullanım etkinliği analizi. Anadolu Tarım Bilimleri Dergisi, 34(1), 57-64

Anonim, (2018). http://cografya.sitesi.web.tr/egimhesaplamalari.html. Erişim: Mayıs 2018.

Anonim,(2019).https://acikders.ankara.edu.tr/pluginfile.ph p/7452/mod_resource/content/0/8.\%20Hafta.pdf. Erişim: Eylül 2019.

Baran, A., Bender, D., \& Özkan, İ. (1996). Organik toprakla karıştırmanın killi tınlı bir toprağın bazı fiziksel özelliklerinde sıkışma ile oluşan değişimlere etkisi. Pamukkale University Journal of Engineering Sciences, 2(1), 81-85

Çelen, i. H., Baran, M. F., Önler, E., \& Bayhan, Y. (2017). Determination of energy balance of apple (Malus domestica) production in Turkey: A case study for Tekirdag province. Anadolu Tarım Bilimleri Dergisi, 32(1), $40-45$.

Demiralay, İ., \& Güresinli, Y. Z. (1979). Erzurum ovası topraklarının kıvam limitleri ve sıkışabilirliği üzerine bir araştırma. Atatürk Ünv. Ziraat Fak. Dergisi, 10(12), 77-93.

ETKB, 2019. https://www.enerji.gov.tr/trTR/Sayfalar/Enerji-Verimliligi. Erişim tarihi: 18.07.19.

Golaszewski, J., Voort, M. V. D., M., Aurich, A. M., Baptista,
F., Balafoutis, A., \& Mikkola, H.J. (2014). Comparative analysis of energy efficiency in wheat production in different climate conditions of Europe. Journal of Agricultural Science and Technology B, 4: 632-640.

Gözübüyük, Z., Demir, O., \& Küçüközdemir, A. (2019). Some operating parameters, energy efficiency, carbon dioxide emission and economic analysis of triticale and wheat grown in high altitude semi-arid climate conditions. Ekin Journal of Crop Breeding and Genetics, 5(1), 42-53.

Iqbal, T. (2007). Energy input and output for production of Boro rice in Bangladesh. Electronic Journal of Environmnetal, Agricultural and Food Chemistry, 7(3), 2717-2722.

IEA. (2019). https://www.iea.org/topics/energyefficiency/. Erişim tarihi: 10.06.2019.

Kayhan, I. E., Çebi, U., \& Kayışoğlu, B. (2013). Reduced tillage soils containing different clay effect of bulk density and porosity. Journal of Agricultural Machinery Science, 9(1), 29-34.

Kuhwald, M., Dörnhöfer, K., Oppelt, N., \& Dutmann, R. (2008). Spatially explicit soil compaction risk assessment of arable soils at regional scale: The SaSCiA-Model, Sustainability, 10(5),1-29

Okant, M. (2012). Şanlıurfa ilinin biyodizel üretim potansiyeli. Harran Tarım ve Gıda Bilimleri Dergisi, 16(4), 11-17.

TÜik. (2018). Bitkisel üretim istatistikleri. http://www.tuik.gov.tr/PreTablo.do?alt_id=1001. Erişim tarihi: 13.06.19.

WEC. (2019).

https://www.worldenergy.org/publications/2019/wo rld-energy issues-monitor-2019-managing-thegrand-energy-transition. Erişim tarihi: 11.09.2019. 